\title{
Estrogen receptor 1 mRNA is a prognostic factor in ovarian carcinoma: determination by kinetic PCR in formalin-fixed paraffin-embedded tissue
} \author{
Guelten Oskay-Özcelik ${ }^{2}$, Claudio Zamagni ${ }^{3}$, Pierandrea De laco ${ }^{4}$, \\ Andrea Martoni ${ }^{3}$, Manfred Dietel and Carsten Denkert \\ Institute of Pathology, Charité Universitätsmedizin Berlin, Charitéplatz 1, 10117 Berlin, Germany \\ ${ }^{1}$ Siemens Healthcare Diagnostics, Cologne, Germany \\ ${ }^{2}$ Department of Gynaecology and Obstetrics, Charité Universitätsmedizin Berlin, Berlin, Germany \\ ${ }^{3}$ Medical Oncology Unit, S.-Orsola-Malpighi Hospital, Bologna, Italy \\ ${ }^{4}$ Obstetrics and Gynaecology Unit, University of Bologna, Bologna, Italy \\ (Correspondence should be addressed to S Darb-Esfahani; Email: silvia.darb-esfahani@ charite.de) \\ *(S Darb-Esfahani, R M Wirtz and B V Sinn contributed equally to this work)
}

Silvia Darb-Esfahani*, Ralph M Wirtz ${ }^{1 *}$, Bruno V Sinn ${ }^{*}$, Jan Budczies, Aurelia Noske, Wilko Weichert, Areeg Faggad, Susanne Scharff', Jalid Sehouli²,

\begin{abstract}
Epidemiological and cell culture studies indicate that ovarian carcinoma growth is dependent on estrogen stimulation. However, possibly due to the lack of a reliable biomarker that helps to select patients according to prognostically relevant estrogen receptor (ER) levels, clinical trials using anti-estrogenic therapeutics in ovarian carcinoma have had inconsistent results. Therefore, we tested if ER expression analysis by a quantitative method might be useful in this regard in formalinfixed paraffin-embedded (FFPE) tissue. In a study group of 114 primary ovarian carcinomas expression of estrogen receptor 1 (ESR1) mRNA was analyzed using a new method for RNA extraction from FFPE tissue that is based on magnetic beads, followed by kinetic PCR. The prognostic impact of ESR1 mRNA expression was investigated and compared to ER $\alpha$ protein expression as determined by immunohistochemistry. In univariate survival analysis the expression level of ESR1 mRNA was a significant positive prognostic factor for patient survival (hazard ratio (HR) 0.230 (confidence interval $(\mathrm{Cl}) 0.102-0.516), P=0.002$ ). ER $\alpha$ protein expression was correlated to ESR1 mRNA expression $(P=0.0001)$; however, ER $\alpha$ protein expression did not provide statistically significant prognostic information. In multivariate analysis, ESR1 mRNA expression emerged as a prognostic factor, independent of stage, grade, residual tumor mass, age, and $\mathrm{ER} \alpha$ protein expression (HR 0.227 ( $\mathrm{Cl} 0.078-0.656), P=0.006$ ). Our results indicate that the determination of ESR1 levels by kinetic PCR may be superior to immunohistochemical methods in assessment of biologically relevant levels of ER expression in ovarian carcinoma, and is feasible in routinely used FFPE tissue.
\end{abstract}

Endocrine-Related Cancer (2009) 16 1229-1239

\section{Introduction}

Ovarian carcinoma is the fifth most common cause of cancer death in women in the US (Jemal et al. 2008). Since this type of tumor is usually detected at an advanced stage, most patients require an extensive surgical therapy with the goal of maximal tumor reduction as well as an adjuvant chemotherapy approach (Winter et al. 2008). The standard chemotherapy strategy is a combination therapy of carboplatin and paclitaxel (Harries \& Gore 2002). Large clinical studies have suggested that the addition of other chemotherapeutic substances does not lead to 
improved clinical outcome (Bookman 2006). Initial response rates to treatment are high; however, most patients finally relapse and die of disease. Salvage chemotherapies show only limited responses and progression-free intervals are generally short. Additionally, classic side effects of these therapies can compromise on the quality of life in these incurable patients. Therefore, new therapeutic strategies for treatment of ovarian carcinoma are urgently needed.

Estrogen receptor (ER) is the prototype of a predictive biomarker. Its expression is used to plan the adjuvant therapy with tamoxifen or aromatase inhibitors in human breast cancer where detection of ER expression by immunohistochemistry is the standard approach (Harvey et al. 1999). Several studies have shown that tumors with high expression of ER show an improved response to tamoxifen or aromatase inhibitors (Fisher et al. 1983, Jakesz et al. 2005).

Estrogens are important regulators of normal ovarian function and there is ample evidence from cell culture studies that ovarian carcinomas are also dependent on estrogen stimulation (Langdon et al. 1994). Furthermore, several epidemiological studies have shown that the risk of ovarian carcinoma is increased after estrogen replacement therapy (Rodriguez et al. 2001, Lacey et al. 2002, 2006, Danforth et al. 2007). However, despite these data from basic research and epidemiology, most clinical trials using antihormonal strategies in patients with recurrent ovarian cancer have yielded disappointing results (Ahlgren et al. 1993, Markman et al. 1996, Karagol et al. 2007, Wagner et al. 2007; Williams CJ 2001 Tamoxifen for relapse of ovarian cancer. Cochrane Database of Systematic Reviews Issue 1 Art No CD001034, www.cochrane.org/reviews/en/ab001034. html). In a recent study by Smyth et al. (2007), a response rate of $17 \%$ has been observed with antiestrogenic therapy in ovarian cancer. In a meta-analysis of several clinical trials including 647 patients, an overall objective response rate of $11 \%$ has been determined, however, there was a wide variation of response rates between 0 and $56 \%$ in the various trials (Tropé et al. 2000). This finding is strongly suggestive of the contribution of tumor-related factors that may be different in the various clinical cohorts. However, so far, there has been no significant correlation between clinical response and the expression of ER (Hatch et al. 1991).

Based on these disappointing results and the clinical need for new therapeutic approaches in ovarian cancer, we have developed the hypothesis that the measurement of ER expression by standard immunohistochemistry, which is the gold standard in breast cancer, may not be suitable for ovarian cancer. Immunohistochemical methods have the disadvantage that the evaluation is only semiquantitative at best and that there is some subjective observer-based component. Therefore, for those types of tumors where only very small differences in biomarker expression may be relevant for biological behavior, the determination of the marker by a more quantitative and highly sensitive method is necessary. Reverse transcription (RT)-PCR is a quantitative method that can easily be performed on small samples; however, its use in formalin-fixed paraffin-embedded (FFPE) tissue has been very limited so far. Nevertheless, several groups have suggested methods to extract RNA from FFPE tissue and to perform a reliable RT-PCR (Paik et al. 2004, Chang et al. 2008).

In this project, we investigated if the determination of ER expression by quantitative RNA-based methods might be a better prognostic factor in FFPE tissue compared to standard immunohistochemistry. To test this hypothesis, we used a study group of 139 ovarian carcinomas. For all tumors, expression of estrogen receptor 1 (ESR1, estrogen receptor alpha, ESRA) was determined by immunohistochemistry. For a subset of 114 tumors, we isolated RNA from FFPE tissue using a new method that is based on magnetic beads and studied ESR1 mRNA expression by kinetic PCR.

\section{Patients, materials, and methods Study population and histopathological examination}

The study group included 139 patients who underwent radical surgery for primary ovarian cancer in the Department of Gynecology and Obstetrics of the Charité University Hospital, Berlin, Germany from 1991 to 2005. Patients were included in the study based on the availability of tissue and follow-up data in the database. Resection specimens of all patients were examined and diagnosed at the Institute of Pathology, Charité University Hospital; Berlin, Germany. Histology and grade were re-evaluated by an experienced gynecopathologist (C D). Hematoxylin and eosin (H\&E) stained sections were cut from paraffin embedded blocks and used for histopathological evaluation; grading of tumors was assessed using the Silverberg grading system (Shimizu et al. 1998). Patients were managed with extensive cytoreductive surgery followed by standard combination chemotherapy; the majority of patients were treated with a platinum-based regimen. Data on intraoperative residual tumor were available for 96 patients. Of these patients $21(21.9 \%)$ had a postoperative residual tumor of $\leq 2 \mathrm{~cm}, 13(13.5 \%)$ of $>2 \mathrm{~cm}$, and 62 patients $(64.4 \%)$ had no macroscopic residual tumor. 
All clinical and pathological characteristics are comparable to the subset of 114 tumors used for mRNA analysis. Follow-up data were available for all patients in the study group. The date of last follow-up was either the date of the event (death or first clinical evidence of disease relapse) or the date of the last follow-up examination without event. Last update of the follow-up data was in October 2007. Follow-up examination was performed every 3 months during the first 3 years after surgery, every 6 months 4 to 5 years after surgery, and annually after the sixth year after surgery. The study has been approved by the institutional review board of the Charite Hospital.

Slide review and all experimental procedures were carried out blinded to the survival status of the patients.

\section{Immunohistochemical staining and evaluation}

Immunohistochemical staining was performed on tissue microarrays, which were constructed by selection of representative tumor areas, which were marked on the routine H\&E stained histological sections. For each case four tissue cores ( $1.5 \mathrm{~mm}$ diameter) from different tumor areas of the sample tissue blocks were punched using a tissue micro-arrayer (Beecher Instruments; Woodland, CA, USA) and embedded into a new paraffin array block.

Immunohistochemical staining was performed using a Ventana Discovery XT instrument (Ventana Medical Systems Inc., Tucson, AZ, USA) according to the manufacturer's instructions. A polyclonal rabbit antibody directed against the C-terminus of human ESRA, diluted 1:50, was applied (Labvision, Freemont, CA, USA). ER immunostaining in tumor cells was evaluated without prior knowledge of clinicopathological parameters and patient outcome. Nuclear immunoreactivity was evaluated according to the percentage of positive cells. As used in the evaluation of breast carcinomas, ER-positive cases were defined as tumors with more than $10 \%$ stained nuclei.

\section{RNA extraction}

A $10-\mu \mathrm{m}$ thick section was cut from each paraffin block and put in a $1.5 \mathrm{ml}$ tube. All tumor samples included in the study contained at least $50 \%$ malignant cells as evaluated by $\mathrm{H} \& \mathrm{E}$ staining. RNA was extracted using a technique based on magnetic beads developed by Siemens Healthcare Diagnostics (Cologne, Germany) according to a standard protocol provided by the manufacturer. In brief, the FFPE section was deparaffinized in xylol and rehydrated in graded solutions of ethanol. The pellet was allowed to dry at room temperature for $10 \mathrm{~min}$, lysed in lysis buffer and
SDS-PAGE for $5 \mathrm{~min}$ at $95^{\circ} \mathrm{C}$. Proteinase $\mathrm{K}$ was added and incubation at $56^{\circ} \mathrm{C}$ with shaking for $2 \mathrm{~h}$ was done. A binding buffer and the magnetic beads were added and nucleic acids were allowed to bind to the beads for $15 \mathrm{~min}$ at room temperature aided by shaking. On a magnetic rack the supernatant was removed and the beads were washed several times with washing buffers. After addition of elution buffer and incubation for $10 \mathrm{~min}$ at $70^{\circ} \mathrm{C}$ with strong shaking, the supernatant was transferred to a new tube without touching the beads. This was followed by DNAse I treatment for $30 \mathrm{~min}$ at $37^{\circ} \mathrm{C}$ then inactivation of DNAse I, using TURBO DNA-free kit according to the procedure provided by the manufacturer (Ambion, Austin, TX, USA); after a short centrifugation the supernatant was taken carefully, kept at $-80{ }^{\circ} \mathrm{C}$ and used for kinetic RT-PCR.

\section{Kinetic RT-PCR}

Intron-spanning primers and TaqMan fluorogenic probes for ESR1 gene and the housekeeping gene RPL37A were provided by Siemens Healthcare Diagnostics. All reactions were performed on an ABI Prism 7900 instrument (Applied Biosytems, Foster City, CA, USA) using the Super Script III One-Step qRT-PCR Kit (Invitrogen) according to the manufacturer's instructions and a reaction volume of $10 \mu \mathrm{l}$ on 384-well plates. PCR conditions were as follows: $30 \mathrm{~min}$ at $60^{\circ} \mathrm{C}$ for $\mathrm{RT}$ and $2 \mathrm{~min}$ at $95^{\circ} \mathrm{C}$ for Taq activation followed by 40 cycles of $95^{\circ} \mathrm{C}$ for $30 \mathrm{~s}$ and $60{ }^{\circ} \mathrm{C}$ for $60 \mathrm{~s}$. Cycle threshold $\left(C_{\mathrm{t}}\right)$ values, which indicate the (interpolated) number of PCR cycles until the fluorescence reached its threshold, were determined. After initial measurement of RPL37A, its $C_{\mathrm{t}}$ value was adjusted to 26 by dilution of each sample. Raw $C_{\mathrm{t}}$ values were measured in triplicates. Each gene was measured three times independently for each tumor sample. $\Delta C_{\mathrm{t}}$ values, which is the difference between mean of the target gene $C_{\mathrm{t}}$ values and the mean of the housekeeping gene $C_{\mathrm{t}}$ values of each sample, were calculated, and $\Delta \Delta C_{\mathrm{t}}$ values $\left(40-\Delta C_{\mathrm{t}}\right)$ were used for statistical analysis, which thereby correlate proportionally to the mRNA expression level of the target gene (Monney et al. 2002, Fiala et al. 2007).

Inclusion criteria of samples for the statistical analysis were as follows: 1) the $C_{\mathrm{t}}$ value for RPL37A lay between 22 and 28, 2) at least a duplicate measurement was available for each gene and sample, 3) the single $C_{\mathrm{t}}$ values were not more than one $C_{\mathrm{t}}$ apart from each other. In our study on ESR1 expression 12 samples were excluded: in ten samples the mean $C_{\mathrm{t}}$ for RPL37A was $>29$; in two samples the $C_{\mathrm{t}}$ for RPL37A was $>1$ between different measurements. 


\section{Statistical evaluation}

Statistic analyses were computed using SPSS 15 (SPSS, Chicago, IL, USA), and GraphPad Prism 4 statistical software (GraphPad Software, San Diego, CA, USA). The Mann-Whitney and Kruskal-Wallis tests were used for correlation with clinical and pathological features. For grouped data, Fisher's exact test was performed. Patient survival in dependence of ESR1 expression was analyzed by the Cox regression model as well as the Kaplan-Meier method and the logrank test. The graph showing hazard ratios (HRs) in dependence of cut-off points was generated with the $\mathrm{R}$ package survival (www.r-project.org). In general, $P$ values $<0.05$ were considered as statistically significant (two-tailed tests).

\section{Results}

\section{Clinical and pathological features of the study group}

A total of 139 cases were studied. The median age of the patient at diagnosis was 57 years with a range between 33 and 81 years. The median follow-up time for event-free patients was 38 months (range 2-118). During this follow-up period, 36 patients (25.9\%) died.

Data on postoperative chemotherapy were available for 128 patients $(92.1 \%)$. The majority of patients (119; $85.6 \%$ ) had received a platinum-based chemotherapy, three patients had received another type of chemotherapy, and six patients, who had been staged FIGO I, had not received chemotherapy. The remaining clinical data are shown in Table 1.

\section{Prognostic value of ESR1 mRNA expression in ovarian carcinoma}

RNA was isolated from a total of 126 paraffinembedded tumor samples and expression of ESR1 was determined by kinetic RT-PCR. Data of 114 cases $(90.5 \%)$ met the quality requirements for statistical analysis; distribution of clinicopathological data and significance of classical prognostic factors were similar as in the whole study group of 139 patients (Table 1). ESR1 mRNA expression $\left(\Delta \Delta C_{\mathrm{t}}\right)$ ranged from 29.00 to 36.42 with a median of $34.39 \Delta \Delta C_{\mathrm{t}}$. The distribution of ESR1 gene expression in the study group is shown in Fig. 1A. $\Delta \Delta C_{\mathrm{t}}$ ESR1 was a favorable prognostic factor in our study group. Separation of the study group by quartiles of ESR1 mRNA expression showed a significant survival difference between patients with low ( $>50 \%$ of study group) as well as high $(<50 \%$ of study group) ESR1 mRNA expression in
Table 1 Clinical and pathological features of the study group

\begin{tabular}{|c|c|c|c|c|}
\hline \multirow[b]{2}{*}{ Parameter } & \multicolumn{2}{|c|}{ Protein analysis } & \multicolumn{2}{|c|}{ RNA analysis } \\
\hline & $\begin{array}{c}\text { Case } \\
\text { number }\end{array}$ & $\begin{array}{c}\text { Percent } \\
(\%)\end{array}$ & $\begin{array}{c}\text { Case } \\
\text { number }\end{array}$ & $\begin{array}{c}\text { Percent } \\
\text { (\%) }\end{array}$ \\
\hline Total & 139 & 100 & 114 & 100 \\
\hline \multicolumn{5}{|c|}{ Age at surgery (years) } \\
\hline$\leq 60$ & 81 & 58.3 & 66 & 57.9 \\
\hline$>60$ & 58 & 41.7 & 48 & 42.1 \\
\hline \multicolumn{5}{|l|}{ Histological type } \\
\hline Serous & 87 & 62.6 & 78 & 68.4 \\
\hline Mucinous & 7 & 5.0 & 4 & 3.5 \\
\hline Endometroid & 18 & 13.0 & 14 & 12.3 \\
\hline Clear cell & 6 & 4.3 & 2 & 1.8 \\
\hline Transitional cell & 7 & 5.0 & 5 & 4.4 \\
\hline Undifferentiated & 14 & 10.1 & 11 & 9.6 \\
\hline \multicolumn{5}{|l|}{ FIGO stage } \\
\hline I & 27 & 19.4 & 20 & 17.5 \\
\hline II & 12 & 8.6 & 9 & 7.9 \\
\hline III & 91 & 65.5 & 79 & 69.3 \\
\hline IV & 9 & 6.5 & 6 & 5.3 \\
\hline \multicolumn{5}{|l|}{ pT } \\
\hline pT1 & 29 & 20.9 & 22 & 19.3 \\
\hline pT2 & 15 & 10.8 & 11 & 9.6 \\
\hline pT3 & 95 & 68.3 & 81 & 71.1 \\
\hline \multicolumn{5}{|l|}{$\mathrm{pN}$} \\
\hline pNO & 55 & 39.6 & 44 & 38.6 \\
\hline $\mathrm{pN} 1$ & 56 & 40.3 & 44 & 38.6 \\
\hline $\mathrm{pNX}$ & 28 & 20.1 & 26 & 22.8 \\
\hline \multicolumn{5}{|l|}{ Silverberg grade } \\
\hline G1 & 22 & 15.8 & 15 & 13.1 \\
\hline G2 & 58 & 41.7 & 49 & 43.0 \\
\hline G3 & 59 & 42.5 & 50 & 43.9 \\
\hline \multicolumn{5}{|c|}{ Residual tumor after surgery } \\
\hline None & 62 & 44.6 & 51 & 44.8 \\
\hline$\leq 2 \mathrm{~cm}$ & 21 & 15.1 & 19 & 16.7 \\
\hline$>2 \mathrm{~cm}$ & 13 & 9.4 & 11 & 9.6 \\
\hline Missing & 43 & 30.9 & 33 & 28.9 \\
\hline \multicolumn{5}{|c|}{ Chemotherapy (CTX) } \\
\hline Platinum-based & 119 & 85.6 & 98 & 86.0 \\
\hline Other CTX & 3 & 2.2 & 2 & 1.7 \\
\hline No CTX & 6 & 4.3 & 4 & 3.5 \\
\hline Missing & 11 & 7.9 & 10 & 8.8 \\
\hline
\end{tabular}

Kaplan-Meier analysis $(P=0.013$; Fig. 1B). To determine an optimum cut-off point for the study group, HRs were plotted against all possible cut-off points. As shown in Fig. 1C, a wide range of cut-offs yielded significant dichotomizations of the study group (upper confidence interval (CI) lower than 1). The lowest HR (0.230) with the narrowest CI (0.102-0.516) was observed by using a cut-off level of $34.10 \Delta \Delta C_{\mathrm{t}}$. Using this cut-off point, a highly significant separation of the study group in patients with a good and an unfavorable prognosis was achieved $(P<0.0001$; Fig. 1D). However, it should be stated that the validity of the $P$ value is limited by the fact that the cut-off point had not been chosen a priori. A Cox regression 

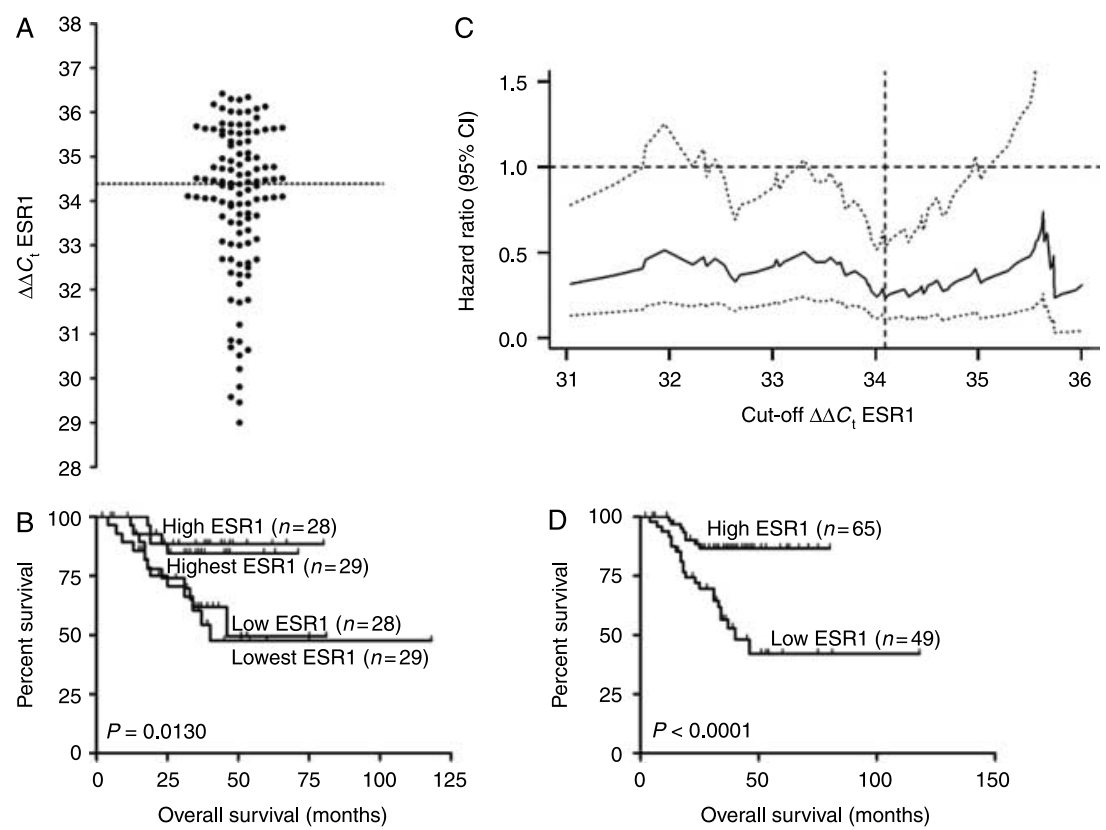

Figure 1 (A) Distribution of the mRNA levels in the study group. Dotted line: median. (B) Survival rate in dependence of quartiles of ESR1 mRNA expression $\left(\Delta \Delta C_{t}\right)$. ESR1 highest, 75-100\%; ESR1 high, 50-75\%; ESR1 low, 25-50\%; ESR1 lowest, 1-25\% of study group. $P$, logrank test. (C) Hazard ratios in dependence of possible cut-off points (solid line). Dotted lines: $95 \%$ confidence interval (Cl); vertical-dashed line, optimal cut-off. (D) Survival rate in dependence of optimal cut-off. High ESR1, $\leq 34.10 \Delta \Delta C_{t}$, Low ESR1, $>34.10 \Delta \Delta C_{\mathrm{t} .}$. , logrank test.

analysis with ESR1 mRNA expression as a continuous variable showed similar results (HR $0.756(95 \% \mathrm{CI}$ $0.634-0.903)$ per $\left.\Delta \Delta C_{\mathrm{t}}(P=0.002)\right)$.

\section{Classical prognostic factors and evaluation of the prognostic effect of ESR1 mRNA in ovarian carcinoma subgroups}

To see if the study group is representative of typical ovarian carcinomas, we evaluated other established prognostic factors. We found that Silverberg grading, presence of residual tumor, as well as the patient age were significant prognostic factors, as known for ovarian carcinoma (not shown). ESR1 mRNA expression was higher in non-serous than in serous and undifferentiated carcinomas $(P=0.049)$, no associations were found with other clinicopathological factors (Fig. 2A).

We evaluated the prognostic role of the ESR1 mRNA in the clinically important subgroups of highstage and high-grade tumors, as well as cases with no residual tumor. In the light of previous studies that showed a differential biomarker expression in different histological types of ovarian carcinoma (Köbel et al. 2008), we further investigated the largest histological subgroup of serous and undifferentiated carcinomas. In all subgroups, we applied the cut-off of $34.10 \Delta \Delta C_{\mathrm{t}}$. As shown in Fig. 2B, the prognostic effect was retained in those major subgroups $(P<0.05)$.

\section{Determination of ER expression by protein analysis}

Using immunohistochemistry, we evaluated ER $\alpha$ protein expression in ovarian carcinoma. We found a highly significant correlation between ER-protein expression and the results of the quantitative PCR $(P<0.0001$; Kruskal-Wallis test $)$; however, there was a high variation of the mRNA levels within the different groups for ER $\alpha$ expression (Fig. 3A).

Neither Cox regression analysis using the percentage of stained tumor cells nor Kaplan-Meier analysis testing multiple different dichotomizations of ER $\alpha$ expression data revealed a significant prognostic effect of ER protein expression (Fig. 3B: optimal dichotomization of the study cohort using a cut-off point of $10 \%$ of stained tumor cells; $P=0.1552$; logrank test).

\section{Multivariate analysis}

In the multivariate analysis all parameters that were significant on univariate analysis were included. Cox regression analysis was performed using the optimal cut-off for ESR1 mRNA expression (Table 2A). In this setting, ESR1 mRNA expression was identified as a prognostic factor independent of age, grade, and residual tumor mass. Patients whose tumors expressed high levels of ESR1 had more than fivefold diminished 


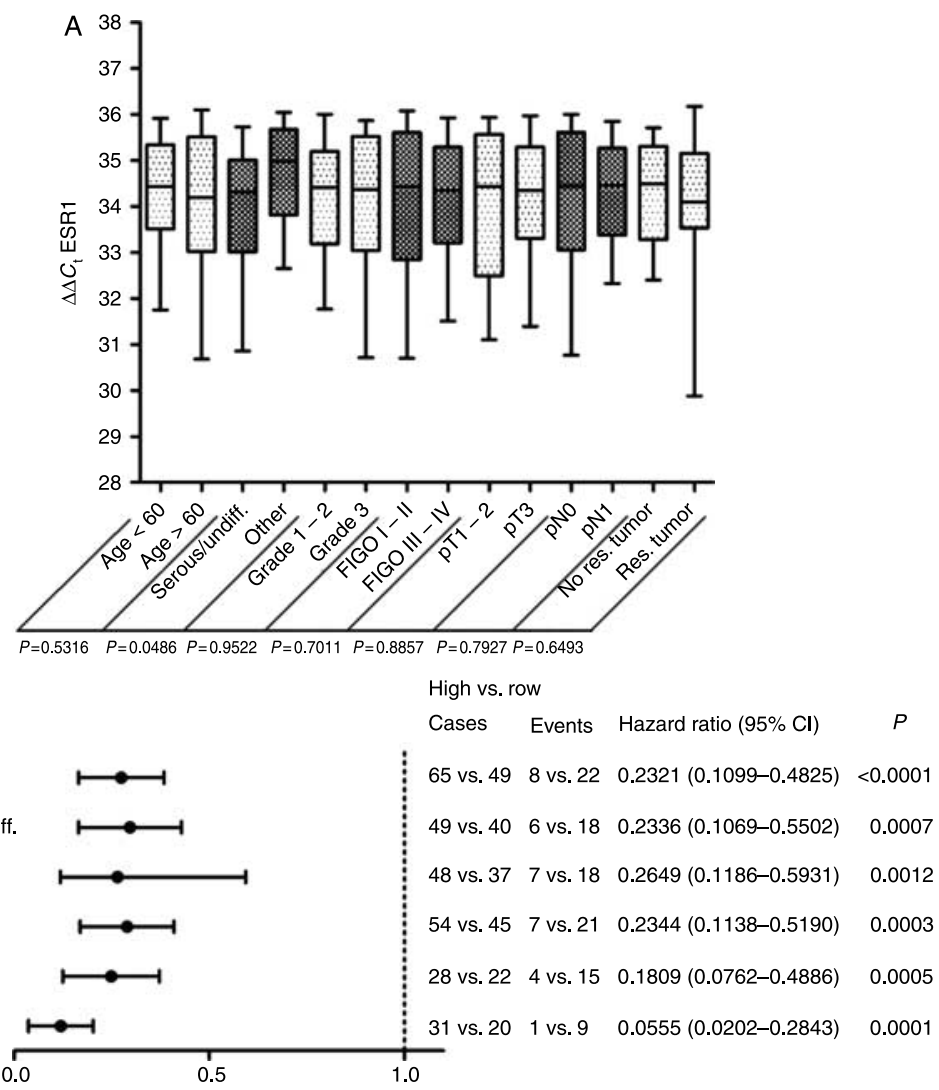

Figure 2 (A) Associations between ESR1 mRNA expression and clinicopathological parameters. Boxes, interquartile range; solid lines, median; whiskers, 10th-90th percentile, $P$, Mann-Whitney test. (B) Prognostic value of ESR1 mRNA expression in important ovarian carcinoma subgroups. The study group was separated by the use of the optimal cut-off point of $34.10 \Delta \Delta C_{\text {t }}$, hazard ratios of ESR1 low expression is set as 1 . Dots, hazard ratio of high ESR1 expression; whiskers, $95 \%$ confidence interval $(\mathrm{Cl}), P$, logrank test.

risk of death than patients with low-level ESR1 expression (HR 0.186 (95\% CI $0.068-0.515)$, $P=0.001)$. Furthermore, patient age and tumor grading were independent prognostic factors in our study group. Similar data were generated using ESR1 mRNA expression as a continuous parameter $(P=0.003$, HR 0.720 per $\Delta \Delta C_{\mathrm{t}}$ (95\% CI 0.580-0.895), not shown).

In a variant multivariate analysis including all traditional prognostic factors as well as ER $\alpha$ protein expression, ESR1 mRNA expression remained a significant prognostic factor (HR 0.227 (CI 0.078-0.656), $\quad P=0.006)$ while $\mathrm{ER} \alpha$ protein expression did not reveal prognostic significance (HR 0.716 (CI 0.264-1.944), $P=0.512$, Table 2B).

\section{Discussion}

Our study evaluates a new quantitative method for the analysis of ER expression using a new method for isolation of mRNA from FFPE tissue followed by kinetic RT-PCR. By comparing the kinetic RT-PCR with conventional immunohistochemistry, we demonstrate that the mRNA expression levels are clearly prognostic over a wide range of different cut-offs, while the protein-based method is not able to detect a prognostically significant expression difference.

This is the first time that the new bead-based RNAextraction method has been tested in samples of ovarian cancer routine FFPE tissue for ER expression. Other studies have investigated hormone receptor expression by immunohistochemistry in ovarian cancer, and found that these receptors were expressed in a large subset of ovarian carcinoma. However, concerning the prognostic role the results were discordant. Several groups report a prognostic effect of progesterone receptor, but not of ER (Kommoss et al. 1992, Münstedt et al. 2000, Hornung et al. 2004, Lee et al. 2005). Some groups reported a positive prognostic effect of ER expression measured by immunohistochemistry (Isola et al. 1990, Høgdall et al. 2007), while other studies did not find any prognostic effect (Scambia et al. 1995, Lu et al. 2006). 

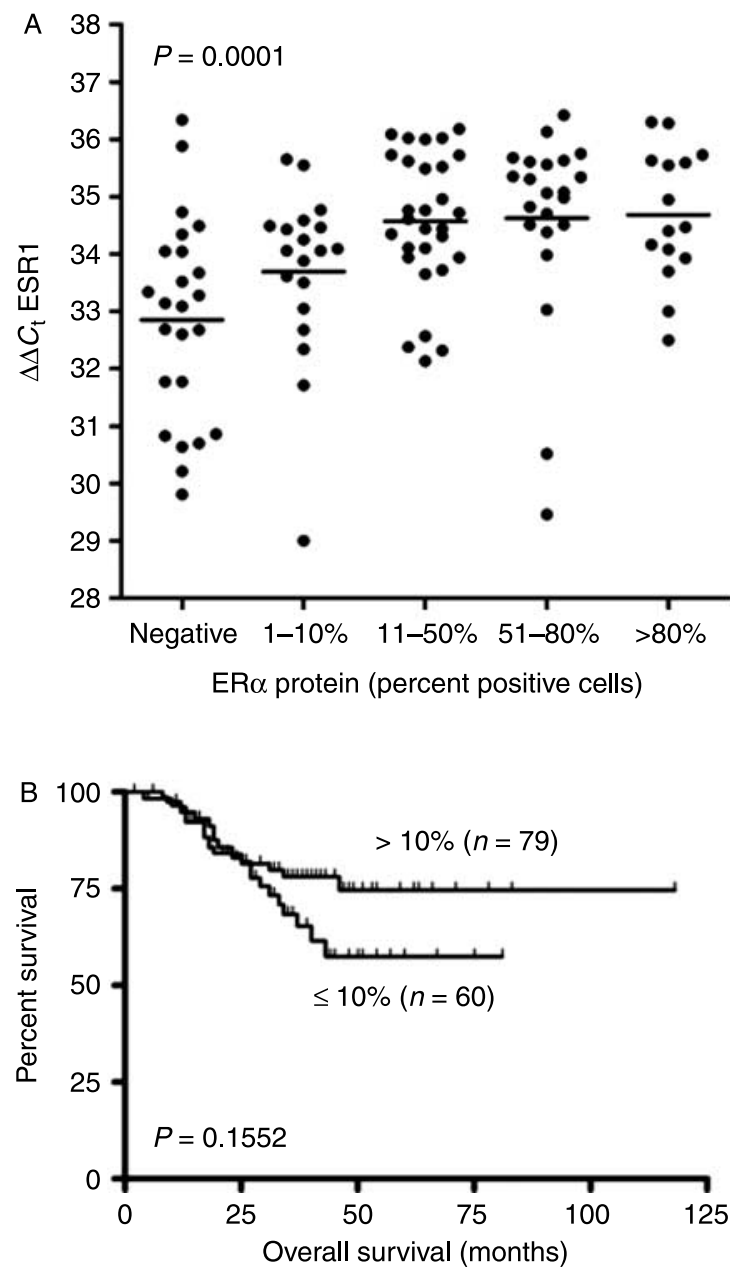

Figure 3 (A) Correlation between $E R \alpha$ protein and mRNA expression. P, Kruskal-Wallis test; solid lines, medians; ESR1 immunoreactivity refers to the rate of positive cells. (B) Survival rate in dependence of $\mathrm{ER} \alpha$ protein expression. $P$, logrank test.

These results from previous studies suggest that immunohistochemistry may not be the ideal method to evaluate ER expression in ovarian cancer, and that quantitative mRNA-based methods may be more suitable for the evaluation of this marker. Two groups have investigated ER expression on the RNA level using fresh frozen ovarian tumor tissue. Chan et al. (2008) found a prognostic impact of ESR2 but not ESR1 mRNA expression; however, the significance of these results is limited by the fact that epithelial and non-epithelial malignant ovarian tumors as well as borderline tumors were evaluated together. Fujimoto et al. (2000) found the ratio ESR2 to ESR1 mRNA to be prognostic for ovarian cancer patients but did not evaluate ER mRNA expression quantitatively and used a very small sample size (28 patients) for the analysis.
Interestingly, using the same method for RNA extraction and quantification from FFPE samples of a large, randomized, multicenter clinical trial on breast cancer, we found that the optimal ESR1 mRNA cut-off to separate ovarian cancer patients according to outcome is very similar to the naturally occurring cutoff of ESR1 mRNA in breast cancer (Pentheroudakis et al. 2009). These data indicate that ESR1 expression levels are similar in both tumor entities.

Estrogens are important regulators of normal ovarian function. Human ovarian surface epithelial (HOSE) cells surround the ovary and play an important role in the repair of the cyclic rupture of the Graafian follicle during ovulation (Murdoch 1996, Katabuchi \& Okamura 2003). HOSE cells are sensitive to estrogen produced by granulosa cells in the developing follicle due to the expression of ER (Lau et al. 1999). In accordance with the function of HOSE cells in the normal ovary, estrogen stimulation results in the

Table 2 Multivariate survival analysis (Cox regression model) for overall survival of patients with invasive ovarian carcinomas

\begin{tabular}{|c|c|c|c|}
\hline & $\begin{array}{c}\text { Hazard } \\
\text { ratio }(\mathrm{HR})\end{array}$ & $\begin{array}{c}95 \% \mathrm{Cl} \\
\text { of } \mathrm{HR}\end{array}$ & $P$ value \\
\hline \multicolumn{4}{|l|}{$A$} \\
\hline $\begin{array}{l}\Delta \Delta C_{\mathrm{t}} \text { ESR1 } \\
\text { (optimal cut-off) }\end{array}$ & 0.186 & $0.068-0.515$ & 0.001 \\
\hline \multicolumn{4}{|l|}{ Grade (Silverberg) } \\
\hline G1-2 & 1.000 & & 0.039 \\
\hline G3 & 2.975 & $1.057-8.371$ & \\
\hline \multicolumn{4}{|l|}{ Residual tumor } \\
\hline $0-2 \mathrm{~cm}$ & 1.000 & & 0.410 \\
\hline$>2 \mathrm{~cm}$ & 1.539 & $0.552-4.287$ & \\
\hline Age (per year) & 1.055 & $1.009-1.103$ & 0.020 \\
\hline \multicolumn{4}{|l|}{$B$} \\
\hline $\begin{array}{l}\Delta \Delta C_{\mathrm{t}} \text { ESR1 } \\
\text { (optimal cut-off) } \\
\text { ER } \alpha \text { protein }\end{array}$ & 0.227 & $0.078-0.656$ & 0.006 \\
\hline$\leq 10 \%$ & 1.000 & & 0.512 \\
\hline$>10 \%$ & 0.716 & $0.264-1.944$ & \\
\hline Age (per year) & 1.056 & $1.004-1.111$ & 0.033 \\
\hline \multicolumn{4}{|l|}{ Grade (Silverberg) } \\
\hline G1-2 & 1.000 & & 0.054 \\
\hline G3 & 2.842 & $0.981-8.235$ & \\
\hline \multicolumn{4}{|l|}{ Residual tumor } \\
\hline $0-2 \mathrm{~cm}$ & 1.000 & & 0.258 \\
\hline$>2 \mathrm{~cm}$ & 1.824 & $0.643-5.170$ & \\
\hline \multicolumn{4}{|l|}{ FIGO stage } \\
\hline FIGO I-II & 1.000 & & 0.655 \\
\hline FIGO III-IV & 1.599 & $0.204-12.559$ & \\
\hline \multicolumn{4}{|l|}{ Histological type } \\
\hline $\begin{array}{l}\text { Serous }+ \\
\text { undifferentiated }\end{array}$ & 1.000 & & 0.333 \\
\hline Non-serous & 1.892 & $0.521-6.869$ & \\
\hline
\end{tabular}

$\mathrm{Cl}$, confidence interval. 
expression of genes regulating proliferation, cell cycle regulation, and energy balance (Syed et al. 2005). Under the hypothesis that recurrent injury of the surface epithelium during ovulation might lead to the accumulation of genetic alterations, which might result in neoplastic transformation, HOSE cells are suggested to constitute the cells of origin of epithelial ovarian cancer (Godwin et al. 1992). However, HOSE cells differ remarkably from ovarian cancer cells in the expression profile of estrogen-regulated genes, i.e. genes with tumor-suppressing functions are upregulated by estrogen stimulation in HOSE cells and downregulated in ovarian cancer cells (Syed et al. 2005). The biological functions of estrogens are mediated by the nuclear ERs that bind to estrogenresponsive elements that are located in the promoter region of target genes. In our study, we focused on ESR1. This ER isoform has been identified as the main isoform in ovarian cancer and an upregulation of ESR1 is a key feature of ovarian carcinomas (O'Donnell et al. 2005), while a loss of ESR2 (estrogen receptor $\beta$, ESRB) has been described in this tumor type (Bardin et al. 2004). Therefore, based on the results obtained with the determination of ESR1 mRNA by array and kinetic PCR in fresh tissue biopsies, we have chosen ESR1 as the main type of ER for our study. In cell culture models, it has been shown that proliferation of ovarian cancer cells is stimulated by estrogens and inhibited by tamoxifen and that this effect is related to the expression level of ER (Langdon et al. 1990). Furthermore, the anti-estrogenic treatment might be synergistic to current standard therapies, since it has been shown in ovarian carcinoma cell lines that the development of resistance to cisplatin is delayed by tamoxifen and antiproliferative effects are increased (McClay et al. 1994, Ercoli et al. 1996).

It may be expected that anti-estrogenic agents are effective predominantly in ovarian carcinomas with active ERs similar to hormone-receptor-positive breast cancers. Considering the fact that several clinical trials have resulted in inconclusive results on the therapeutic benefit of anti-estrogenic medications, a better system for biomarker assessment in ovarian cancer is definitely needed in order to identify the patients who would benefit from such medication. In the early clinical trials, it has been suggested that a semiquantitative immunohistological scale could be used as an inclusion criterion for clinical trials (Bowman et al. 2002, Smyth et al. 2007). However, ER expression level is a continuous parameter; therefore, it is difficult to identify the relevant threshold for biologically important ER expression. In our study, ER protein expression was highly correlated to mRNA expression, yet, within the different groups for the immunoreactive score measuring the protein expression, there was a considerably high variation of the mRNA levels, indicating that for single cases the protein expression may not measure the complete range of receptor expression. This may explain the fact that we found mRNA expression but not protein expression to show a prognostic impact although both parameters were correlated.

Interesting research topics for future studies will be the evaluation of the mechanisms of ESR 1 mRNA overexpression, such as ESR1 gene amplification that has been reported in breast and endometrial carcinoma (Holst et al. 2007, Lebeau et al. 2008). Similarly, progesterone receptor expression might be helpful in the prediction of patient prognosis and therapy response and should be investigated further.

In this study, we demonstrate that the determination of ER levels by kinetic PCR yields better results with respect to survival prediction than immunohistological methods in assessment of ER expression in ovarian carcinoma and may be a valuable method for the identification of those cases where ER expression is of biological significance. Most importantly, this analysis is feasible in routine FFPE tissue. Therefore, further clinical studies should use this new technique to measure ER expression and to define quantitative inclusion criteria for anti-estrogenic therapies. This might be an approach to reduce the high variability of response rates that has been observed in the various clinical trials and a contribution to a more individualized therapy in ovarian cancer.

\section{Declaration of interest}

Ralph M Wirtz and Susanne Scharff are employees of Siemens Healthcare Diagnostics, Cologne, Germany. According to all other authors, there is no conflict of interest that could be perceived as prejudicing the impartiality of the research reported.

\section{Funding}

This research did not receive any specific grant from any funding agency in the public, commercial or not-for-profit sector.

\section{Acknowledgements}

We would like to thank Ms Lisa Glanz and Ms Petra Wachs for their excellent technical assistance and Ms Martina Eickmann for her assistance in editing the manuscript. 


\section{References}

Ahlgren JD, Ellison NM, Gottlieb RJ, Laluna F, Lokich JJ, Sinclair PR, Ueno W, Wampler GL, Yeung KY, Alt D et al. 1993 Hormonal palliation of chemoresistant ovarian cancer: three consecutive phase II trials of the Mid-Atlantic Oncology Program. Journal of Clinical Oncology 11 1957-1968.

Bardin A, Boulle N, Lazennec G, Vignon F \& Pujol P 2004 Loss of ERbeta expression as a common step in estrogendependent tumor progression. Endocrine-Related Cancer 11 537-551.

Bookman MA 2006 GOG0182-ICON5: 5-arm phase III randomized trial of paclitaxel and carboplatin vs combinations with gemcitabine, PEG-lipososomal doxorubicin, or topotecan in patients with advanced-stage epithelial ovarian or primary peritoneal carcinoma. Journal of Clinical Oncology 24256.

Bowman A, Gabra H, Langdon SP, Lessells A, Stewart M, Young A \& Smyth JF 2002 Clin CA125 response is associated with estrogen receptor expression in a phase II trial of letrozole in ovarian cancer: identification of an endocrine-sensitive subgroup. Cancer Research $\mathbf{8}$ 2233-2239.

Chan KK, Wei N, Liu SS, Xiao-Yun L, Cheung AN \& Ngan HY 2008 Estrogen receptor subtypes in ovarian cancer: a clinical correlation. Obstetrics and Gynecology 111 144-151.

Chang JC, Makris A, Gutierrez MC, Hilsenbeck SG, Hackett JR, Jeong J, Liu ML, Baker J, Clark-Langone K, Baehner FL et al. 2008 Gene expression patterns in formalin-fixed, paraffin-embedded core biopsies predict docetaxel chemosensitivity in breast cancer patients. Breast Cancer Research and Treatment 108 233-240.

Danforth KN, Tworoger SS, Hecht JL, Rosner BA, Colditz GA \& Hankinson SE 2007 A prospective study of postmenopausal hormone use and ovarian cancer risk. British Journal of Cancer 96 151-156.

Ercoli A, Scambia G, De Vincenzo R, Alimonti A, Petrucci F, Fattorossi A, Isola G, Benedetti Panici P, Caroli S \& Mancuso S 1996 Tamoxifen synergizes the antiproliferative effect of cisplatin in human ovarian cancer cells: enhancement of DNA platination as a possible mechanism. Cancer Letters 108 7-14.

Fiala M, Liu PT, Espinosa-Jeffrey A, Rosenthal MJ, Bernard G, Ringman JM, Sayre J, Zhang L, Zaghi J, Dejbakhsh S et al. 2007 Innate immunity and transcription of MGAT-III and Toll-like receptors in Alzheimer's disease patients are improved by bisdemethoxycurcumin. PNAS 104 12849-12854.

Fisher B, Redmond C, Brown A, Wickerham DL, Wolmark N, Allegra J, Escher G, Lippman M, Savlov E, Wittliff J et al. 1983 Influence of tumor estrogen and progesterone receptor levels on the response to tamoxifen and chemotherapy in primary breast cancer. Journal of Clinical Oncology $1227-241$.
Fujimoto J, Hirose R, Sakaguchi H \& Tamaya T 2000 Clinical significance of expression of estrogen receptor alpha and beta mRNAs in ovarian cancers. Oncology 58 334-341.

Godwin AK, Testa JR, Handel LM, Liu Z, Vanderveer LA, Tracey PA \& Hamilton TC 1992 Spontaneous transformation of rat ovarian surface epithelial cells: association with cytogenetic changes and implications of repeated ovulation in the etiology of ovarian cancer. Journal of the National Cancer Institute 15 592-601.

Harries M \& Gore M 2002 Part I: chemotherapy for epithelial ovarian cancer-treatment at first diagnosis. Lancet Oncology 3 529-536.

Harvey JM, Clark GM, Osborne CK \& Allred DC 1999 Estrogen receptor status by immunohistochemistry is superior to the ligand-binding assay for predicting response to adjuvant endocrine therapy in breast cancer. Journal of Clinical Oncology 17 1474-1481.

Hatch KD, Beecham JB, Blessing JA \& Creasman WT 1991 Responsiveness of patients with advanced ovarian carcinoma to tamoxifen. A Gynecologic Oncology Group study of second-line therapy in 105 patients. Cancer 68 269-271.

Høgdall EV, Christensen L, Høgdall CK, Blaakaer J, Gayther S, Jacobs IJ, Christensen IJ \& Kjaer SK 2007 Prognostic value of estrogen receptor and progesterone receptor tumor expression in Danish ovarian cancer patients: from the 'MALOVA' ovarian cancer study. Oncology Reports 18 1051-1059.

Holst F, Stahl PR, Ruiz C, Hellwinkel O, Jehan Z, Wendland M, Lebeau A, Terracciano L, Al-Kuraya K, Jänicke F et al. 2007 Estrogen receptor alpha (ESR1) gene amplification is frequent in breast cancer. Nature Genetics 39 655-660.

Hornung R, Urs E, Serenella E, Edward W, Ursula S, Urs H \& Daniel F 2004 Analysis of potential prognostic factors in 111 patients with ovarian cancer. Cancer Letters 206 97-106.

Isola J, Kallioniemi OP, Korte JM, Wahlström T, Aine R, Helle M \& Helin H 1990 Steroid receptors and Ki-67 reactivity in ovarian cancer and in normal ovary: correlation with DNA flow cytometry, biochemical receptor assay, and patient survival. Journal of Pathology 162 295-301.

Jakesz R, Jonat W, Gnant M, Mittlboeck M, Greil R, Tausch C, Hilfrich J, Kwasny W, Menzel C, Samonigg H et al. 2005 ABCSG and the GABG. Switching of postmenopausal women with endocrine-responsive early breast cancer to anastrozole after 2 years' adjuvant tamoxifen: combined results of ABCSG trial 8 and ARNO 95 trial. Lancet 366 455-462.

Jemal A, Siegel R, Ward E, Hao Y, Xu J, Murray T \& Thun MJ 2008 Cancer statistics 2008. CA: A Cancer Journal for Clinicians 58 71-96.

Karagol H, Saip P, Uygun K, Caloglu M, Eralp Y, Tas F, Aydiner A \& Topuz E 2007 The efficacy of tamoxifen in patients with advanced epithelial ovarian cancer. Medical Oncology 24 39-43. 
Katabuchi H \& Okamura H 2003 Cell biology of human ovarian surface epithelial cells and ovarian carcinogenesis. Medical Electron Microscopy 36 74-86.

Köbel M, Kalloger SE, Boyd N, McKinney S, Mehl E, Palmer C, Leung S, Bowen NJ, Ionescu DN, Rajput A et al. 2008 Ovarian carcinoma subtypes are different diseases: implications for biomarker studies. PLoS Medicine 5 e232.

Kommoss F, Pfisterer J, Thome M, Schäfer W, Sauerbrei W \& Pfleiderer A 1992 Steroid receptors in ovarian carcinoma: immunohistochemical determination may lead to new aspects. Gynecologic Oncology 47 317-322.

Lacey JV Jr, Mink PJ, Lubin JH, Sherman ME, Troisi R, Hartge P, Schatzkin A \& Schairer C 2002 Menopausal hormone replacement therapy and risk of ovarian cancer. Journal of the American Medical Association 288 334-341.

Lacey JV Jr, Brinton LA, Leitzmann MF, Mouw T, Hollenbeck A, Schatzkin A \& Hartge P 2006 Menopausal hormone therapy and ovarian cancer risk in the National Institutes of Health-AARP Diet and Health Study Cohort. Journal of the National Cancer Institute $\mathbf{9 8}$ 1397-1405.

Langdon SP, Hawkes MM, Lawrie SS, Hawkins RA, Tesdale AL, Crew AJ, Miller WR \& Smyth JF 1990 Oestrogen receptor expression and the effects of oestrogen and tamoxifen on the growth of human ovarian carcinoma cell lines. British Journal of Cancer 62 213-216.

Langdon SP, Crew AJ, Ritchie AA, Muir M, Wakeling A, Smyth JF \& Miller WR 1994 Growth inhibition of oestrogen receptor-positive human ovarian carcinoma by anti-oestrogens in vitro and in a xenograft model. European Journal of Cancer 30A 682-686.

Lau KM, Mok SC \& Ho SM 1999 Expression of human estrogen receptor-alpha and -beta, progesterone receptor, and androgen receptor mRNA in normal and malignant ovarian epithelial cells. PNAS 96 5722-5727.

Lebeau A, Grob T, Holst F, Seyedi-Fazlollahi N, Moch H, Terracciano L, Turzynski A, Choschzick M, Sauter G \& Simon R 2008 Oestrogen receptor gene (ESR1) amplification is frequent in endometrial carcinoma and its precursor lesions. Journal of Pathology 216 151-157.

Lee P, Rosen DG, Zhu C, Silva EG \& Liu J 2005 Expression of progesterone receptor is a favorable prognostic marker in ovarian cancer. Gynecologic Oncology 96 671-677.

Lu L, Katsaros D, Wiley A, Rigault de la Longrais IA, Risch HA, Puopolo M \& Yu H 2006 The relationship of insulin-like growth factor-II, insulin-like growth factor binding protein-3, and estrogen receptor-alpha expression to disease progression in epithelial ovarian cancer. Clinical Cancer Research 12 1208-1214.

Markman M, Iseminger KA, Hatch KD, Creasman WT, Barnes W \& Dubeshter B 1996 Tamoxifen in platinum-refractory ovarian cancer: a Gynecologic Oncology Group Ancillary Report. Gynecologic Oncology 62 4-6.
McClay EF, Albright KD, Jones JA, Christen RD \& Howell SB 1994 Tamoxifen delays the development of resistance to cisplatin in human melanoma and ovarian cancer cell lines. British Journal of Cancer 70 449-452.

Monney L, Sabatos CA, Gaglia JL, Ryu A, Waldner H, Chernova T, Manning S, Greenfield EA, Coyle AJ, Sobel RA et al. 2002 Th1-specific cell surface protein Tim-3 regulates macrophage activation and severity of an autoimmune disease. Nature 31 536-541.

Münstedt K, Steen J, Knauf AG, Buch T, von Georgi R \& Franke FE 2000 Steroid hormone receptors and long term survival in invasive ovarian cancer. Cancer $\mathbf{8 9}$ 1783-1791.

Murdoch WJ 1996 Ovarian surface epithelium, ovulation and carcinogenesis. Proceedings of the Cambridge Philosophical Society. Biological Sciences 71 529-543.

O'Donnell AJ, Macleod KG, Burns DJ, Smyth JF \& Langdon SP 2005 Estrogen receptor-alpha mediates gene expression changes and growth response in ovarian cancer cells exposed to estrogen. Endocrine-Related Cancer 12 851-866.

Paik S, Shak S, Tang G, Kim C, Baker J, Cronin M, Baehner FL, Watson D, Bryant J, Costantino JP et al. 2004 A multigene assay to predict recurrence of tamoxifen-treated, node-negative breast cancer. New England Journal of Medicine 351 2817-2826.

Pentheroudakis G, Kalogeras KT, Wirtz RM, Grimani I, Zografos G, Gogas H, Stropp U, Pectasides D, Skarlos D, Hennig G et al. 2009 Gene expression of estrogen receptor, progesterone receptor and microtubuleassociated protein Tau in high-risk early breast cancer: a quest for molecular predictors of treatment benefit in the context of a Hellenic Cooperative Oncology Group trial. Breast Cancer Research and Treatment 116 131-143.

Rodriguez C, Patel AV, Calle EE, Jacob EJ \& Thun MJ 2001 Estrogen replacement therapy and ovarian cancer mortality in a large prospective study of US women. Journal of the American Medical Association 285 1460-1465.

Scambia G, Benedetti-Panici P, Ferrandina G, Distefano M, Salerno G, Romanini ME, Fagotti A \& Mancuso S 1995 Epidermal growth factor, oestrogen and progesterone receptor expression in primary ovarian cancer: correlation with clinical outcome and response to chemotherapy.

British Journal of Cancer 72 361-366.

Shimizu Y, Kamoi S, Amada S, Hasumi K, Akiyama F \& Silverberg SG 1998 Toward the development of a universal grading system for ovarian epithelial carcinoma. Gynecologic Oncology 70 2-12.

Smyth JF, Gourley C, Walker G, MacKean MJ, Stevenson A, Williams AR, Nafussi AA, Rye T, Rye R, Stewart M et al. 2007 Antiestrogen therapy is active in selected ovarian cancer cases: the use of letrozole in estrogen receptorpositive patients. Clinical Cancer Research $\mathbf{1 3}$ 3617-3622. 
Syed V, Zhang X, Lau KM, Cheng R, Mukherjee K \& Ho SM 2005 Profiling estrogen-regulated gene expression changes in normal and malignant human ovarian surface epithelial cells. Oncogene 24 8128-8143.

Tropé C, Marth C \& Kaern J 2000 Tamoxifen in the treatment of recurrent ovarian carcinoma. European Journal of Cancer 36 S59-S61.

Wagner U, du Bois A, Pfisterer J, Huober J, Loibl S, Lück HJ, Sehouli J, Gropp M, Stähle A, Schmalfeldt B et al. 2007 AGO Ovarian Cancer Study Group. Gefitinib in combination with tamoxifen in patients with ovarian cancer refractory or resistant to platinum-taxane based therapy - a phase II trial of the AGO Ovarian Cancer Study Group (AGO-OVAR 2.6). Gynecologic Oncology 105 132-137.

Winter WE III, Maxwell GL, Tian C, Sundborg MJ, Rose GS, Rose PG, Rubin SC, Muggia F \& McGuire WP 2008 Gynecologic Oncology Group. Tumor residual after surgical cytoreduction in prediction of clinical outcome in stage IV epithelial ovarian cancer: a Gynecologic Oncology Group Study. Journal of Clinical Oncology 26 83-89. 